\title{
Ohranjanje regionalne raznolikosti stanovanjske hiše v Sloveniji
}

\author{
Vladimir Drozg \\ Dr., Oddelek za geografijo, Pedagoška fakulteta, Univerza v Mariboru, \\ Koroška 160, 2000 Maribor, Slovenija \\ e-mail: vlado.drozg@uni-mb.si
}

\section{Izvleček}

Prispevek obravnava problem ohranjanja regionalne raznolikosti pri novih stanovanjskih hišah in način vključevanja oblikovnih določil v sistem urejanja naselij. Pri tem sta ključni dve vprašanji: 1. kaj ohranjati (kateri fiziognomski elementi vzpostavljajo identiteto regionalnega stavbarstva) in 2. kako ohranjati (kakšen naj bo režim ohranjanja v posameznih pokrajinah).

Ključne besede: hiša, urejanje naselij, poselitvena območja, podeželje

\section{Preserving Regional Diversity in Residential Buildings in Slovenia}

\begin{abstract}
The article deals with the problem of preserving a regional varaity of new constructions and the way how to incorporate the preserving regime in the system of settlement regulation. Two questions were disscoused: 1 . what to preserve - which morphological features of authentic construction should new constructions imitate in order to preserve the regional identity of the buildings? and 2. how to preserve how should regulations be incorporated into the system of settlement regulation?
\end{abstract}

Key words: House, settlement regulation, settlement areas, countryside 


\section{UVOD}

Raznolikost, ena od bistvenih značilnosti Slovenije, se, vsaj kar zadeva stanovanjsko hišo in podobo naselij, vse bolj izgublja, bledi. Zaradi pomanjkljivih določil o oblikovanju novogradenj in zapostavljene prenove objektov, so novogradnje, kljub temu da nastajajo na kulturnozgodovinsko in pokrajinsko različnih območjih, bolj podobne med seboj, kakor avtohtonim stavbam. Takšen razvoj ocenjujemo kot neprimeren, saj se izgubljajo regionalne raznolikosti, kvaliteta novogradenj je marsikdaj $\mathrm{v}$ bolečem nasprotju $\mathrm{z}$ avtohtonim stavbarstvom, posledica česar je vizualna degradacija pokrajine in razvrednotenje podobe naselij. Sodobne smernice urejanja naselij in oblikovanja objektov močno odstopajo od uveljavljene graditeljske prakse v Sloveniji. V kulturno razvitih državah je stavbna dediščina razumljena kot nacionalna in kulturna vrednota, ki jo je potrebno ohranjati in razvijati. Določila o oblikovanju novogradenj so zato prilagojena regionalnemu stavbarstvu.

Za izboljševanje razmer in odpravljanje tega problema sta potrebna dva ukrepa: sprememba razmerja med prenovljenimi objekti in novogradnjami ter večje upoštevanje regionalnih značilnosti stavbarstva pri oblikovanju novogradenj. Za to pa je v prvi vrsti potrebna opredelitev oblikovnih določil, ki izhajajo iz regionalnih značilnosti stavbarstva in ustrezen način vključevanja $v$ planske in urbanistične dokumente. V zvezi s slednjim ukrepom je potrebno pojasniti:

- katere oblikovne značilnosti avtohtonega stavbarstva naj novogradnje povzemajo, da bo ohranjena regionalna identiteta objektov

- kako naj bodo določila vključena v sistem urejanja naselij

Ideja o tem v naši urbanistični praksi ni nova. D. Moškon se zanjo zavzema v svoji knjigi Kako graditi lepšo hišo na Slovenskem, čeprav je niti analitično, niti implikativno ni razdelal (Moškon 1992 :136-146). Tudi P. Fister s sodelavci je v študiji Arhitekturne krajine obdelal regionalne značilnosti arhitekture, vendar brez potrebne konkretizacije in usmeritev za oblikovanje novogradenj. Ne nazadnje o tovrstnih določilih govori Zakon o urejanju naselij, ko opredeljuje potrebo po varovanju naselbinske podobe (člen 9; UL SRS št. 18/84).

Namen pričujočega prispevka je opredeliti stavbne elemente, ki jih kaže upoštevati pri načrtovanju novogradenj ter podati možen način reševanja problema. 


\section{KAJ OHRANJATI}

Nakazali smo že, da sta za ohranjanje regionalnih značilnosti stavbarstva potrebna dva ukrepa:

- dosledno varovanje in prenova obstoječih objektov,

- upoštevanje oblikovnih značilnosti regionalnega stavbarstva v načrtovanju novogradenj.

Oba pristopa nista daleč vsak k sebi. Kot pravi P. Fister, so merila za vrednotenje in določevanje oblikovnih kvalitet novogradenj "določljiva le s kategorijami identitete prostora, $\mathrm{z}$ merili dediščine in z vrednotami ekološko osveščenega človekovega bivanja" (Fister 1992 :465). Postavlja pa se vprašanje, kateri so tisti stavbni elementi, ki jih je v duhu kontinuitete potrebno upoštevati pri oblikovanju novogradenj. To najbrž niso vsi, saj bi v tem primeru šlo za konzervacijo in ohranjanje preživetega. Tak odgovor tudi ni skladen z idejo kontinuitete; slednje namreč pomeni posebno aktualizacijo preteklosti, ki aktualizira le tiste dele, ki lahko najdejo oporišče v sedanjosti. Ali z drugimi besedami: relevantni so tisti elementi, ki so bistveni za ohranjanje regionalnih značilnosti stavbarstva in katerih funkcija je ob današnjem načinu življenja še aktualna ali jo je možno prilagoditi potrebam sedanjosti. Kateri so ti elemeti, je potrebno šele opredeliti.

Do odgovora na to vprašanje smo se dokopali s pomočjo gestalt teorije. Ta namreč pravi, da vsi elementi neke celote nimajo enakega pomena (Metzger 1975 :178). Nekateri členi so za funkcioniranje in izgled celote pomembnejši, pomen drugih pa je bolj prikrit. Če elemente, ki predstavljajo obliko hiše razdelimo po pomenu, dobimo naslednje:

elementi 1. reda (pomembnejši elementi)

- tloris (razmerje med dolžino in širino)

- volumen (razmerje med dolžino, širino in višino)

- naklon strehe

elementi 2. reda (manj pomembni elementi)

- konstrukcijski stavbni členi (v smislu položaja in velikosti): fasadne odprtine, podstrešne line in okna, zunanji hodnik (gank), vetrolov, talni zidec, podstrešni venec, kletna okna, stebri in arkade, napušč, čopi na strehi, vrsta in barva kritine

\section{elementi 3. reda}

- dekorativni stavbni členi: okrasje v lesu, kamnu ali ometu, šivani robovi vogalov, vratni in okenski okvirji, stenske poslikave

- material

- kolorit 
Ker je prikazan postopek razvrščanja fiziognomskih elementov zelo subjektiven, smo se opredeljevanja ključnih stavbnih elementov lotili še na drugi način. Predpostavljali smo, da bi s primerjanjem oblikovnih značilnosti tipov kmečke hiše s tipsko podobo nove stanovanjske hiše lahko spoznali največja odstopanja med enimi in drugimi. Največja odstopanja so tudi oblikovno najbolj moteči elementi, kar je potrebno pri oblikovanju novogradenj upoštevati. $\mathrm{V}$ ta namen smo izdelali morfometrijsko primerjavo med tipi hiš. Upoštevali smo dimenzije in druge stavbne značilnosti preko 200 objektov iz različnih koncev Slovenije. S tem smo pridobili tudi nekaj empiričnih podatkov o morfometrijskih značilnostih fiziognomskih elementov različnih tipov hiš.

Tabela 1: Oblikovne značilnosti tipov kmečke hiše in nove stanovanjske hiše.

\begin{tabular}{|c|c|c|c|c|c|}
\hline \multirow[b]{2}{*}{ element } & \multicolumn{4}{|c|}{ tipi kmečke hiše } & \multirow[b]{2}{*}{ nova hiša } \\
\hline & alpski & kraški & panonski & $\begin{array}{l}\text { osrednje- } \\
\text { slovenski }\end{array}$ & \\
\hline tloris ( $\check{s}: d)$ & $1: 1,2-1,5$ & $1: 2-2,5$ & $1: 2-2,5$ & $1: 1,5-2$ & $1: 1-1,5$ \\
\hline $\begin{array}{l}\text { volumen } \\
(\check{s}: \mathrm{d}: \mathrm{v})\end{array}$ & $1: 1,2-1,5: 1$ & $1: 2-2,5: 1,2-1,5$ & $1: 2-2,5: 1$ & $1: 1,5-2: 1$ & $1: 1-1,5: 1,5-2$ \\
\hline naklon strehe & $43^{\circ}-50$ & $15-25^{\circ}$ & $40-45^{\circ}$ & $40-45^{\circ}$ & $30-40^{\circ}$ \\
\hline vrsta kritine & $\begin{array}{l}\text { bobrovec, } \\
\text { les }\end{array}$ & korci & bobrovec & bobrovec & $\begin{array}{l}\text { bobrovec, } \\
\text { tegola, salo- } \\
\text { nitne plošče }\end{array}$ \\
\hline $\begin{array}{l}\text { značilni } \\
\text { konstrukcijski } \\
\text { stavbni členi }\end{array}$ & $\begin{array}{l}\text { čop, } \\
\text { zunanji } \\
\text { hodnik }\end{array}$ & $\begin{array}{l}\text { stebri, por- } \\
\text { ton, zunanji } \\
\text { hodnik }\end{array}$ & napušč & $\begin{array}{l}\text { čop, strešna } \\
\text { okna, napušč }\end{array}$ & $\begin{array}{l}\text { balkon, } \\
\text { strešna okna, } \\
\text { vetrolov, } \\
\text { terasa }\end{array}$ \\
\hline $\begin{array}{l}\text { značilni } \\
\text { dekorativni } \\
\text { stavbni členi }\end{array}$ & $\begin{array}{l}\text { okrasje } \\
\text { v lesu, } \\
\text { stenske } \\
\text { poslikave }\end{array}$ & $\begin{array}{l}\text { okrasje } \\
\text { v kamnu }\end{array}$ & $\begin{array}{l}\text { okrasje } \\
\text { v ometu, } \\
\text { okenski } \\
\text { in vratni } \\
\text { okvirji }\end{array}$ & $\begin{array}{l}\text { okrasje } \\
\text { v ometu, } \\
\text { okenski } \\
\text { in vratni } \\
\text { okvirji, } \\
\text { šivani robovi }\end{array}$ & - \\
\hline material & les, kamen & kamen & $\begin{array}{l}\text { opeka, } \\
\text { blato, les }\end{array}$ & opeka, les & $\begin{array}{l}\text { opeka, ste- } \\
\text { klo, kovina, } \\
\text { kamen }\end{array}$ \\
\hline
\end{tabular}

Iz preglednice je razvidno, da so največje razlike med avtohtonimi tipi hiš in novimi hišami v tlorisu (ta je pri novih hišah skoraj kvadraten, pri starih pa praviloma pravokoten), naklonu strehe, ki je povsod, razen na Krasu strmejša na starih kot na novih hišah, volumnu objektov, ta je pri novih hišah praviloma 
večji, in v stavbnih členih, kjer so nekateri dodani (npr. balkon, vetrolov), številni pa odvzeti (zunanji hodnik, šivani robovi, okenski okvirji). Očitno tudi je, da, upoštevaje fiziognomske elemente 1. reda, razlike med avtohtonimi tipi hiš niso prav velike. Večje so v fiziognomskih elementih 3. reda, torej dekorativnih stavbnih členih.

Slika 1: Volumensko razmerje med stanovanjsko hišo iz 70-tih let in vzhodnoosrednejslovensko ter primorsko hišo
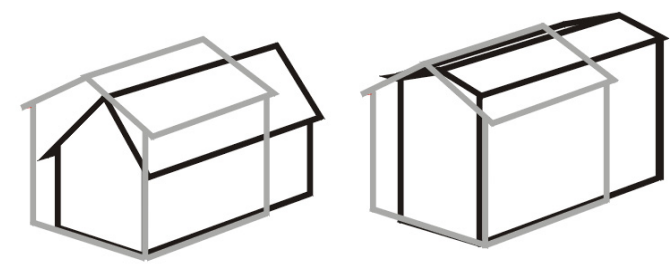

Iz tega bi lahko povzeli, da so elementi, ki ustvarjajo regionalno identiteto hiš in bi jih bilo potrebno upoštevati tudi pri novogradnjah, naslednji: tlorisno razmerje, volumensko razmerje, naklon strehe in posamezni dekorativni stavbni členi, ki pomenijo regionalno posebnost (npr. porton na Krasu, frčade na Dolenjskem, poslikave na Gorenjskem, čopi v osrednji Sloveniji, les kot gradbeni material na Koroškem, okenski okvirji in šivani robovi na Štajerskem).

\section{KAKO OHRANJATI}

V nadaljevanju je potrebno ponazoriti, kako ta spoznanja vključiti v sistem urejanja naselij. Prav gotovo ni primerno, da bi vse novogradnje, tako v mestih kot na podeželju, morale odsevati enako, pravzaprav ruralno podobo. Tudi ni ustrezno, da bi za vsa naselja, tako za obmestna naselja kot za naselja na podeželju, veljala enotna merila za oblikovanje novogradenj. Zato menimo, da je potreben selektiven pristop k oblikovanju objektov. Dosedanji predlogi o varovanju stavbnih značilnosti so temeljili na izboru stavbnih elementov, ki jih morajo novogradnje na območju, kjer se pojavlja določen tip kmečke hiše, upoštevati. Po takem pristopu se novogradnje v bližini mest ne bi bistveno razlikovale od novogradenj sredi podeželja. Zato predlagamo, da se stopnja ohranjanja stavbnih značilnosti prilagaja strukturnim značilnostim prostora (tudi $\mathrm{v}$ tem primeru je ideja kontinuitete aktualna), tako da za različne dele prostora 
velja različen režim ohranjanja. $\mathrm{V}$ tem smislu sta ključni dve vprašanji:

1. katera območja kažejo strukturne značilnosti prostora in se razlikujejo po urejevalskih določilih o urejanju naselij

2. v čem se razlikujejo usmeritve za oblikovanje objektov v izbranih območjih.

Glede prvega vprašanja menimo, da ponujajo t.i. poselitvena območja pravi odgovor. Poselitvena območja združujejo naselja, za katera veljajo iste usmeritve za urejanje. Opredelimo jih z elementi, ki se neposredno povezujejo z urejanjem naselij. Ključni dejavnik pri načrtovanju naselij je prebivalstvo oziroma njegove socioekonomske značilnosti. Prostorske ureditve so namreč namenjene ljudem; ker ne živijo vsi enakega načina življenja, morajo biti ureditve ustrezno diferencirane oziroma prilagojene potrebam ljudi, njihovim dejavnostim oziroma socioekonomskim razmeram. V tem smislu lahko ločimo naslednja območja socioekonomskih značilnosti, ki se med seboj razlikujejo po dinamiki demografskega razvoja in socio-ekonomski strukturi prebivalstva: (več o tem glej Drozg 2000): mesta, obmestja, urbanizirano podeželje, manj urbanizirano podeželje ter neposeljena in redko poseljena območja.

$\mathrm{Na}$ obravnavani problem lahko gledamo tudi iz drugega zornega kota. Izhodišče za opredeljevanje območij je različen režim ohranjanja avtohtonega stavbarstva. Na podeželju oziroma v območjih, kjer prevladuje agrarna pokrajina, želimo ohraniti obliko objektov, ki odražajo ruralne značilnosti. V urbanih območjih je tovrstna potreba manjša, zato naj oblikovanje objektov odraža predvsem značilnosti urbanega okolja. Tako obstajata dve skrajnosti: območja, kjer je možno in potrebno ohranjati in razvijati avtohtone oblike naselij in stanovanjske hiše, ter urbana območja, kjer je oblikovanje objektov svobodnejše. Obstaja še prehodno območje, kjer se prepletajo urbani in ruralni vplivi in kjer je možno razviti novo oblikovno identiteto naselij. Iz povedanega sledi, da je možno opredeliti tri območja oblikovnih značilnosti:

- Območja večje ohranjenosti avtohtonega stavbarstva. To je večinoma manj urbanizirano podeželje, kjer je kmetijstvo še prevladujoča gospodarska dejavnost. Značilnosti avtohtonega stavbarstva in prvotne zasnove naselij so dobro razpoznavne kljub novogradnjam, ki odstopajo od nekdanjih oblikovnih meril. Za omejitev tega območja lahko uporabimo iste kazalce kot za kategorijo "manj urbanizirano podeželje".

- Območja manjše ohranjenosti avtohtonega stavbarstva. To so bolj urbanizirani deli podeželja, kjer je še razpoznavna identiteta ljudskega stavbarstva, ali pa je to identiteto treba ponovno vzpostaviti. Vsebinsko se prekrivajo s kategorijo "urbanizirano podeželje".

- Urbana območja, kjer so oblikovna določila manj vezana na značilnosti avtohtonega stavbarstva in zato niso predmet našega prispevka. 


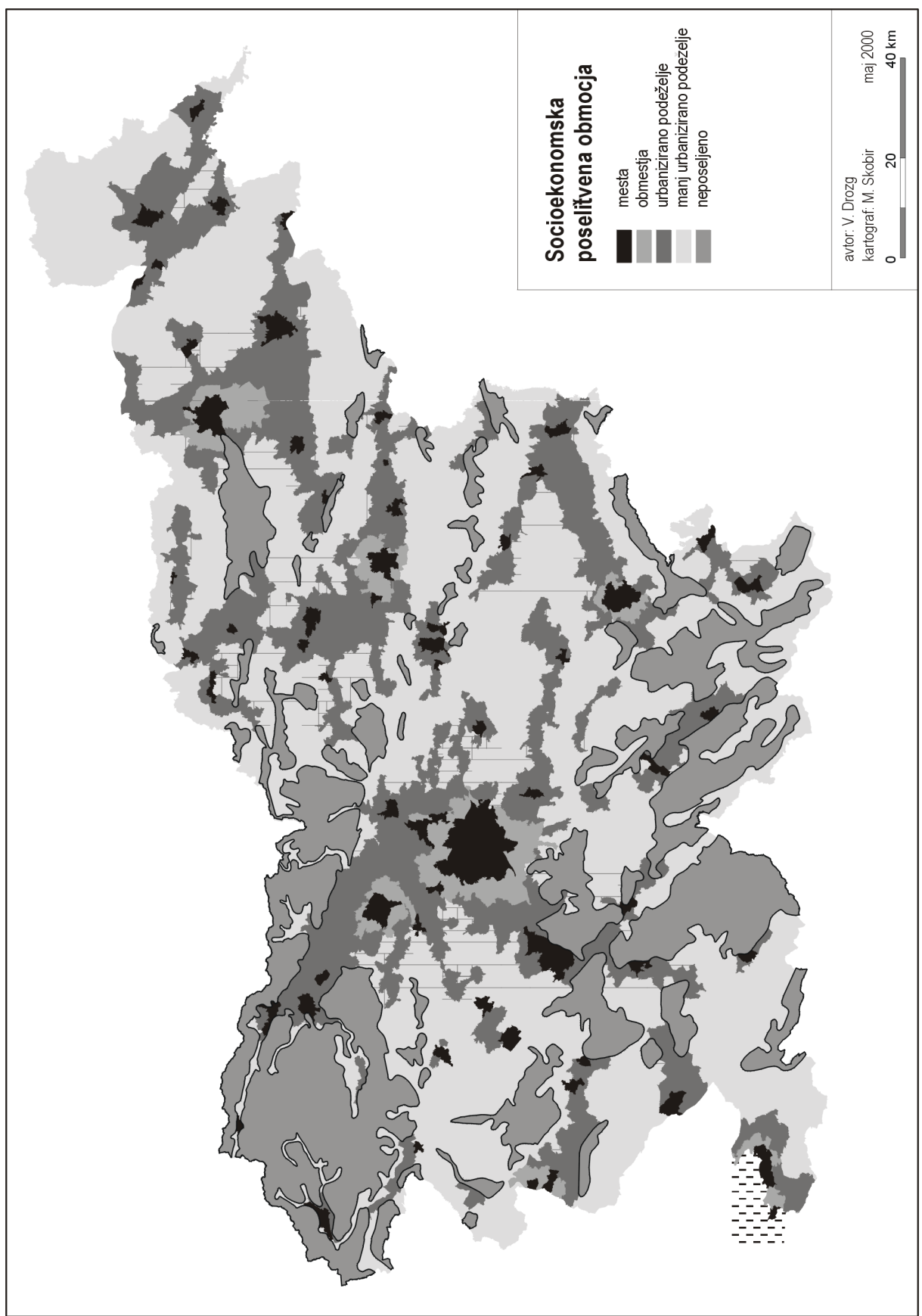

Slika 2: Socioekonomska poselitvena območja 
Glede drugega vprašanja izhajamo iz prepričanja, da socioekonomske razmere posredno določajo tudi oblikovalska določila. V urbanih območjih, kjer je socioekonomska struktura prebivalstva bolj urbana, je tudi oblikovanje novogradenj manj prilagojeno stavbarstvu iz podeželja; in obratno, na manj urbaniziranem podeželju je stopnja upoštevanja avtohtonega stavbarstva večja. Takšno izhodišče je v skladu s temeljno idejo urejanja prostora, ki govori o potrebi upoštevanja lokalnih razmer in o potrebi prilagajanja strukturnim značilnostim prostora. Pri tem nikakor ni vseeno, katere fiziognomske elemente novogradnje povzemajo oziroma ohranjajo. $Z$ elementi 1 . reda se ohranjata pejsaž in kubus, z elementi 3. reda pa detajl. Po gestalt teoriji so pomembnejši elementi hkrati nosilci "identitete", določajo izgled (pogosto tudi funkcijo) celote, manj pomembni elementi pa so nekakšno dopolnilo, spomin, asociacija na izvor oblike (Metzger 1975 :193). Iz tega bi lahko sklepali, da so za ohranjanje regionalnih značilnosti pomembnejši elementi 1. reda, ostali fiziognomski elementi pa imajo bolj posredno, asociativno vlogo na oblike avtohtonega stavbarstva.

Pri izboru oziroma tehtanju fiziognomskih elementov je primerno upoštevati še cilje oziroma namen, ki si ga $\mathrm{z}$ ohranjanjem avtohtonega stavbarstva zastavljamo. Kot rečeno, želimo ustaviti nadaljnjo degradacijo podobe naselij (pokrajine) in doseči oblikovno skladnost med avtohtonim stavbarstvom in novogradnjami. S tem imamo $\mathrm{v}$ mislih ohranjanje pejsaža pokrajine, ne pa ohranjanje spomina na stavbarsko preteklost, kakršnega izpričujejo stavbni detajli. Oblikovno enakih objektov kot so stare kmečke hiše seveda ni mogoče graditi. To tudi ne bi bilo smiselno - stavbni tipi se morajo razvijati, ne pa posnemati. Vendar je potrebno težiti k ohranjanju (in upoštevanju) izvornih značilnosti; ohraniti je potrebno osnovni "modul" in ga nadgraditi s sodobnimi likovnimi prvinami. Zato menimo, da se priporočilo za oblikovanje novogradenj lahko nanaša samo fiziognomske elemente 1. reda.

Menimo da je primerno, če novogradnje na območjih večje ohranjenosti avtohtonega stavbarstva, to je na neposeljenem in redko poseljenem območju ter na manj urbaniziranem podeželju povzemajo vsaj naslednje elemente avtohtonega stavbarstva: naklon strehe in volumensko razmerje objektov. Priporočljivo je povzemanje nekaterih regionalno značilnih dekorativnih stavbnih elementov (kolorit, gradbeni material).

Novogradnje na območjih manjše ohranjenosti avtohtonega stavbarstva, t.j. na urbaniziranem podeželju, naj povzemajo najmanj naklon strehe ter približno tlorisno razmerje objektov.

Seveda je oboje potrebno razumeti bolj kot priporočilo, kakor določilo. Takšen predlog pomeni namreč veliko, skoraj grobo poenostavljanje oblik avtohtonih objektov. Po eni strani zanemarja bogastvo detajlov posameznih tipov hiš, socialne razlike, ki so se odražale tudi v tipih zgradb in variante po- 
sameznega stavbnega tipa. Po drugi strani pa $\mathrm{v}$ graditeljsko prakso vnaša vsaj minimalne standarde o oblikovanju novogradenj in s tem omejuje degradacijo pokrajine in naselij.

\section{Slika 3: Primeren naklon strehe na novih stanovanjskih objektih}

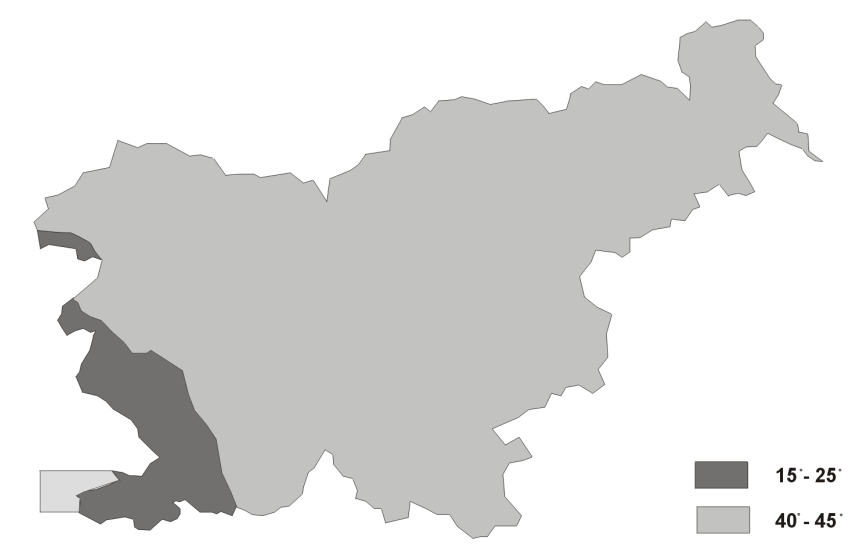

Primeren naklon strehe na novih stanovanjskih objektih

avtor: V. Drozg, 2002

Slika 4: Primeren tloris in volumen novih stanovanjskih objektov

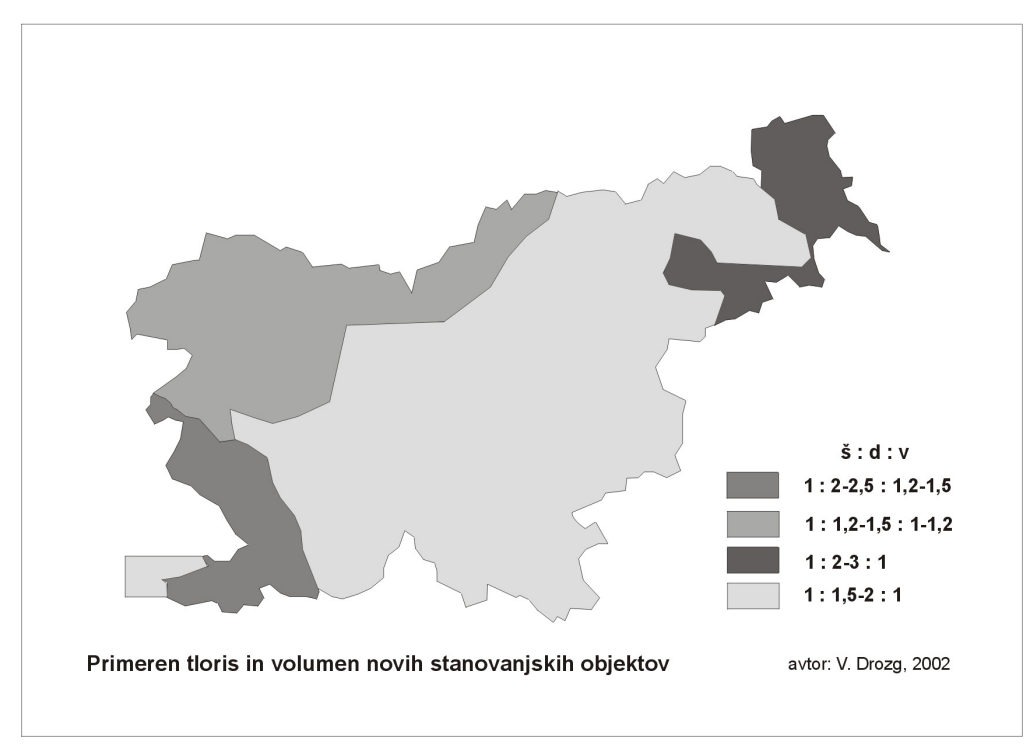




\section{VKLJUČEVANJE OBLIKOVNIH DOLOČIL V PLANSKE DOKUMENTE}

Pri implementaciji spoznanega se pojavlja še en problem; določiti je potrebno "mejne vrednosti" fiziognomskih elementov in njihovo regionalno razmestitev, kar je podlaga za pripravo planskih dokumentov na državni in občinski ravni.

Najbrž tudi ni realno pričakovati, da bi z novogradnjami ohranjali vso paleto stavbnih tipov. Normirana določila je skoraj nemogoče ustrezno prevesti v normativni jezik, kakršen se uporablja v planskih dokumentih. Poleg tega se ni mogoče izogniti splošni standardizaciji in unifikaciji življenja, kar se prenaša tudi na način gradnje in opremljanje stanovanjskih hiš. Kot smo že omenili, se stavbni tipi med seboj bolj razlikujejo po manj pomembnih elementih, kakor po pomembnih. Zato menimo, da je realneje ohranjati značilnosti 3 do 4 osnovnih stavbnih tipov (npr. alpskega, primorskega, panonskega in osrednjeslovenskega), ostale pa ohranjati predvsem s priporočili, osveščanjem graditeljev in izdelovalcev stanovanjske opreme. $\mathrm{V}$ ta namen smo na podlagi generaliziranih morfometrijskih značilnosti avtohtonih stanovanjskih hiš opredelili mejne vrednosti izbranih fiziognomskih elementov in zarisali njihovo regionalno razmestitev. Tako formulirani fiziognomski elementi so lahko sestavni del planskih dokumentov na državni in občinski ravni.

\section{Literatura:}

Deu Živa, 2001, Stavbarstvo slovenskega podeželja. Ljubljana, Kmečki glas

Drozg Vlado, 1992, Razvijanje in ohranjanje podeželskih naselij. Urbani izziv št.21-22, Urbanistični inštitut, 11-14

Drozg Vladimir, 1998, Kmečka hiša. Geografski atlas Slovenije. Ljubljana, DZS, 296-297

Drozg Vladimir, Deu Živa, Konečnik Kunst Marinka, Premzl Vilibald, 2000, Poselitvena območja in usmeritve ter merila za urejanje naselij. Urad za prostorsko planiranje, Ljubljana

Fister Peter, 1993, Črne gradnje kot dediščina časa, prostora in družbe. Teorija in praksa št. 5-6/let. 30, 465

Metzger Wofgang, 2001 (6. izd.), Psychologie. Darmstadt, Steinkopf, 178-192

Metzger Wolfgang, 1975, Gesetze des Sehens, Frankfurt, Kramer, 122-126

Moškon Dušan,1992, Kako graditi lepšo hišo na Slovenskem. Maribor, Obzorja, 136-146

Trieb Michael et all, 1985, Erhaltung und Gestaltung des Ortsbildes. Stuttgart, Kohlhammer 


\section{PRESERVING REGIONAL DIVERSITY IN RESIDENTIAL BUILDINGS IN SLOVENIA}

\section{Summary}

Diversity, one of the essential features of Slovenia, is being increasingly lost in the appearance of houses and settlements. We believe that such developmental trends are detrimental as they contribute to the loss of regional diversity. Furthermore, the quality of new constructions is often in painful conflict with that of authentic buildings. The result is a visual degradation of the landscape and devaluation of the settlements' image. Two measures need to be taken in order to rectify the situation and eliminate the problem: change the ratio between renovated buildings and new constructions on the one hand, and give greater consideration to regional features of building in new constructions on the other. In implementing this last requirement, we need to consider the following questions:

- Which morphological features of authentic construction should new constructions imitate in order to preserve the regional identity of the buildings?

- How should regulations be incorporated into the system of settlement regulation?

The purpose of this article is to determine relevant elements of regional construction, present their local distribution and suggest possible solutions to the problem.

\section{What to preserve}

Which architectural elements should be taken into account in planning new constructions in order to ensure the continuity of construction development? To answer this question we used the gestalt theory, which states that not all elements of a whole are equally important. Some are more important in terms of function and appearance, while the value of others is less overt. The more important elements are crucial in terms of "identity" because they determine the appearance of a whole. Among the most important elements that determine the appearance of a house are the elements of the $1^{\text {st }}$ order:

- ground plan (the ratio between the length and the width)

- volume (the ratio between the length, the width and the height)

- slope of the roof the elements of the $2^{\text {nd }}$ order (less important elements)

- construction architectural elements (in terms of position and size): façade openings, attic dormers and windows, balcony (corridor), windbreak, parapet wall, cornice, basement windows, pillars and arcades, jutting roof, hipped ends, type and color of roofing the elements of the $3^{\text {rd }}$ order 
- decorative architectural elements: wooden, stone or plaster decorations, stitched corner edges, door and window frames

- material

- coloration

The process of identifying crucial architectural elements is highly subjective, which is why we decided to employ another method as well, i.e. a comparison of morphological features of typical farm houses and typical new constructions. Our decision was based on the assumption that such comparison will show the greatest discrepancies between the two types. The largest discrepancies are at the same time the most intrusive morphological elements and this needs to be taken into consideration while planning new constructions. With this in mind, we prepared a morphometric comparison of different house types. We found that the biggest differences exist between authentic types of houses and new constructions in the ground plan (this is almost square in the shape of new constructions, but rectangular in old ones), slope of the roof, which is always steeper in new houses than it is in the old ones (the only exception being the buildings in Karst), the volume of the houses (the new ones are as a rule bigger in size), and in architectural elements (with some, such as balconies and windbreaks, being added and many, such as painted angles and window frames, being omitted).

It follows that the relevant architectural elements that create the regional identity of houses and therefore need to be taken into consideration while building new ones are: the ground plan ratio, the volume ratio, the roof slope and individual decorative architectural elements typical of a particular region.

\section{How to preserve}

It would certainly be inappropriate for all new constructions, those in town and those in the country, to reflect a rural image. Similarly, there can be no uniform regulations for new constructions in the suburbs and in countryside settlements. Rather, a selective approach to planning constructions is necessary. We suggest that the degree of preserving architectural features should be adjusted to the structural characteristics of the area, i.e. different regimes of preservation apply to different parts of regions. Accordingly, we divided the entire territory of Slovenia into several socio-economic regions: towns, suburbs, urbanized countryside, less urbanized countryside, unsettled areas and sparsely populated areas

In urban areas, where the socio-economic structure of the population is more urbanized, the planning of new constructions is obviously less compatible with countryside constructions; and vice versa, in less urbanized countryside areas the authentic architecture should be taken into consideration to a much greater degree. We believe that it suffices if new constructions in unset- 
tled areas, in sparsely populated areas, and in less urbanized countryside should try to incorporate at least the following characteristics: roof slope, volume ratio and some decorative architectural elements. New constructions in the areas with a lesser degree of authentic architecture, i.e. in the urbanized countryside should likewise take into account at least roof slope and an approximate ground plan ratio of individual residential buildings.

\section{Incorporating morphological regulations into planning documentation}

It is perhaps unrealistic to expect that new constructions will be able to preserve the entire range of building types. It is more reasonable to try and preserve the characteristics of three or four basic building types (e.g. the Alpine, the Mediterranean, the Pannonian and the Central-Slovene one), while the preservation of the others should be encouraged through recommendations, awareness raising of builders and the manufacturers of housing equipment and through renovation. On the basis of generalized morpho-metric characteristics of authentic houses we thus identified the critical values of selected physiognomic elements and prepared maps of their regional distribution (see cartographic appendices). 